\title{
O004. Refractory chronic cluster headache responding absolutely to indomethacin
}

\author{
Carlo Lisotto $^{1 *}$, Federico Mainardi ${ }^{2}$,Ferdinando Maggioni ${ }^{1}$, Giorgio Zanchin ${ }^{1}$ \\ From Abstracts from the 1st Joint ANIRCEF-SISC Congress \\ Rome, Italy. 29-31 October 2015
}

\section{Background}

Cluster Headache $(\mathrm{CH})$ attacks typically respond to triptans, in particular to subcutaneous sumatriptan and/or to inhaled oxygen. These treatments are effective in most cases. Anecdotal evidence suggests that some $\mathrm{CH}$ patients may respond absolutely to indomethacin, as do patients with paroxysmal hemicrania $(\mathrm{PH})$ and hemicrania continua $(\mathrm{HC})$. We report the case of a male with refractory chronic $\mathrm{CH}$, who responded both acutely and prophylactically to indomethacin.

\section{Materials and methods}

Following the International Classification of Headache Disorders (ICHD-3 beta) criteria, we diagnosed chronic $\mathrm{CH}$ in a 72-year-old male, whose headaches started when he was 56 . For the first 4 years $\mathrm{CH}$ was episodic and later became chronic, with short remission periods lasting less than 1 month. The pain was strictly left-sided and was accompanied by conjunctival injection, lacrimation and nasal congestion. During most of the attacks the patient felt restless and had pacing activity. The mean frequency of headaches was two per day, one often occurring at night during sleep, and their duration was about 20-30 minutes. MRI and Angio-MRI of the brain were within normal limits.

\section{Results}

The patient's attacks did not respond to subcutaneous sumatripan and oxygen inhalation. Interestingly, the patient noticed that his headaches would promptly and completely subside by injecting $50 \mathrm{mg}$ intramuscular indomethacin. The patient was previously treated prophylactically with verapamil, prednisone and lithium, reporting no

\footnotetext{
* Correspondence: carlo.lisotto@aas5.sanita.fvg.it

'Headache Centre, Department of Neurosciences, University of Padua, Padua, Italy

Full list of author information is available at the end of the article
}

benefit. Given the absolute response to acute parenteral indomethacin, the patient was commenced with preventive oral indomethacin at the dose of $50 \mathrm{mg}$, three times daily. He showed a complete response in 10 days after the start of treatment; a tapering of the dose consistently led to the relapse of headaches.

\section{Conclusions}

The clinical features and, to a certain extent, also the pathophysiology of both $\mathrm{PH}$ and $\mathrm{HC}$, which respond in an absolute way to indomethacin, considerably overlap with those of $\mathrm{CH}$. Indomethacin is largely considered to be ineffective in patients with $\mathrm{CH}$, but a response to this drug is not contrary to the diagnostic criteria for $\mathrm{CH}$ [1]. Our case fulfils the ICHD-3 beta criteria for both chronic $\mathrm{CH}$ and also for probable chronic $\mathrm{PH}$, lacking one criterion, i.e. frequency of attacks. The review of the literature suggests that indomethacin-responsive $\mathrm{CH}$ exists and that some cases may be misdiagnosed when one relies on therapeutic responsiveness to make a diagnosis. This seems to be particularly true for chronic $\mathrm{CH}$, whose clinical characteristics may overlap with those of chronic $\mathrm{PH}$ [2].

Written informed consent to publication was obtained from the patient(s).

\footnotetext{
Authors' details

${ }^{1}$ Headache Centre, Department of Neurosciences, University of Padua, Padua, Italy. ${ }^{2}$ Headache Centre, Hospital of Venice, Venice, Italy.
}

Published: 28 September 2015

\section{References}

1. Prakash S, Shah ND, Chavda BV: Cluster headache responsive to indomethacin: case reports and a critical review of the literature. Cephalalgia 2010, 30:975-982.

2. Buzzi MG, Formisano R: A patient with cluster headache responsive to indomethacin: any relationship with chronic paroxysmal hemicrania? Cephalalgia 2003, 23:401-404. 
doi:10.1186/1129-2377-16-S1-A96

Cite this article as: Lisotto et al:: 0004. Refractory chronic cluster headache responding absolutely to indomethacin. The Journal of Headache and Pain 2015 16(Suppl 1):A96.

\section{Submit your manuscript to a SpringerOpen ${ }^{\circ}$ journal and benefit from:}

- Convenient online submission

- Rigorous peer review

- Immediate publication on acceptance

- Open access: articles freely available online

- High visibility within the field

- Retaining the copyright to your article

Submit your next manuscript at $\gg$ springeropen.com 